\title{
Accounting
}

\section{Unravelling the factors affecting agriculture profitability enterprise: Evidence from coconut smallholder production}

\author{
Zubaidah Omar ${ }^{\mathrm{a}}$ and Fazleen Abdul Fatah ${ }^{\text {* }}$
}

\section{${ }^{a}$ Faculty of Plantation and Agrotechnology, Universiti Teknologi MARA, Jasin Campus, 77300 Merlimau, Jasin, Melaka. Malaysia}

\begin{tabular}{l}
\hline C H R O N I C L E \\
\hline Article history: \\
Received March 222020 \\
Received in revised format March \\
302020 \\
Accepted April 142020 \\
Available online \\
April 142020 \\
\hline Keywords: \\
Coconut \\
Production \\
Malaysia \\
Profitability \\
Productivity
\end{tabular}

\section{Introduction}

Coconut (Cocos nucifera L.) is an important member in Arecaceae family (palm family). Coconut palm can grow up to 30 metres tall with 6 long pinnate leaves and 60 until 90 centimetres pinnate. The coconut palm is called as a 'Tree of Life' because of its multiple uses and of great utility (Green, 1991; Naik, 2017). Coconut palm is a perennial crop, which is cultivated largely in the tropics and subtropics regions including India, Philippines, Malaysia, Sri Lanka and India Ocean. To date, the coconut palm has been grown in 90 countries which mostly has been concentrated in Asia and the Pacific area (Pham, 2016). The Green Revolution of the 1960s has been accentuated into rapid increase in food crop production and cereals such as wheat, rice, maize and others. Similarly, efforts have been made to achieve similar importance in nonfood crop production such as coconut, tea, sugarcane, palm oil and cotton. It was noted that the Coconut palm provides livelihoods for a large number of population around the world and serves as food security particularly in Asian Pacific Countries. In 2014, Indonesia alone produced more than 18

\footnotetext{
* Corresponding author.

E-mail address: fazleen5201@uitm.edu.my (F. Abdul Fatah) 
million metric tons (mt) of coconut while it was estimated about 12 million populations in India were dependent on the coconut sector as major employments in cultivation, processing and downstream activities (Vinodhini \& Deshmukh, 2017).

In Malaysia, coconut sector is divided into two types which are estate or plantation and smallholders. Over $90 \%$ of coconut plantation is classified as smallholders that usually own land holdings of less than one hectare. Coconut areas under the smallholding sector can be found in Peninsular Malaysia, Sabah and Sarawak which is estimated to be between 90,000 and 100,000 smallholders (Sivapragasam, 2008). Malaysia remains as one of top 10 coconut producing countries in the world and coconut is among important industrial crops after oil palm, paddy and rubber. In 2010, the country's production of coconut was 550,140 metric tonnes and in 2013, the production was then increased to 624,152 metric tonnes. However, the production of coconut has started to decline from 2014 until 2016 before it remained stable at 500,000 metric tonnes in the following years (FAOSTAT, 2016). There are many factors that affect the productivity and profitability in coconut industry. According to Laksana (2003), socio demographic such age, gender, marital status, family size, number of family dependent burden, level of education, experience and income are influencing farmers' work and performance. Herath et al. (2015) explained that low productivity has a negative relationship with low experience or education level. They asserted that farmers who may not have experience or knowledge to handle their farms may find difficulties in handling pest attack or plant diseases rather than farmers who possessed more technical knowledge and completed higher education level. In addition, Hussain and Hanjra (2004) explained that quality of education and experience will lead to higher production and yield because farmers were likely to adopt new system and good agricultural practices and know how to mitigate the risks if anything happen to their crop. They further explained that "poor knowledge will remain poor income". It is therefore noted that important factors for agriculture development are through knowledge, good experience and education (Asfaw \& Admassies, 2004).

On the other hand, extension agent plays important roles in disseminating information and technical knowledge, guiding proper communication approaches and good channels to influence smallholders to adopt with a new technology (Akinbile \& Otitolaye, 2008). According to Christoplos (2012), extension agent can challenge the smallholders to conduct from "business as usual" to better production and higher income of smallholders if information is delivered to smallholders effectively. Moreover, it was noted that an extension agent played significant roles in providing training skill and seminar to smallholders in which may help smallholders have a proper knowledge and guidance to on their farming and thus gained more production and increased their productivity (Rivera, 2011). In particular, profitability will measure the success of the farm and productivity of the market. Hifza (2011) highlighted that the profitability is the most important element for company and organization. Profitability can be determined as owner's wealth which explains the performance or progress of enterprise or organization. Besides that, without profitability, the enterprise or organization cannot survive and may incur losses. Higher profitability means larger return of investment and have better performance. Profitability also shows that an enterprise or an organization gets lower cost and higher return or more revenue of business given the availability of inputs or resources they possess.

Considering the significant importance of coconut sector to the livelihoods of smallholders, this research is therefore conducted to determine the profitability of the coconut smallholder production in Batu Pahat, Johor, Malaysia and to gain better insight on the status of socio economics and the coconut sector in Malaysia. To date, there has been no empirical study to determine the profitability and factors affecting production of coconut in Malaysia. Yet empirical evidences on the farm level of profitability in coconut production is limited and knowledge of smallholders' production and socioeconomic situations are scanty particularly in Malaysia. This constitutes a gap in research that formed the basis for this study.

\section{Methodology}

\subsection{Location of Study}

DOA (2017) reported that Batu Pahat district in Johor is the most productive area of coconut in Malaysia produced by smallholders (Table 1). The total production by smallholders in Batu Pahat was about 43,644 mt. The samples were taken from three districts in Batu Pahat, which were Peserai, Parit Raja and Rengit. Using a sample random sampling, the sample size is 152 while the population of coconuts smallholders in Batu Pahat or all these districts are altogether 253 smallholders. The population in Rengit is 128 respondents and the sample size is about 76 respondents. Other districts such as Peserai and Parit Raja have 55 respondents and 70 respondents respectively and thus the sample size for these two districts are 33 respondents and 43 respondents. Subsequently, a sample size is determined based on Krejcie and Morgan (1970). This sampling design is used to determine respondents for interview with the help of structured questionnaire which seems to be an effective method to determine the factors and relationship of all variables or problems. For the analysis of data, budgeting technique and cost concepts such as variables cost, fixed cost and total cost, benefit cost ratio and multiple regression were used in this study. 
Table 1

Production of Coconut in Johor (2017)

\begin{tabular}{|c|c|c|c|}
\hline Districts & Production (metric tonnes) & Districts & Production (metric tonnes) \\
\hline Batu Pahat & 45000 & Mersing & 3647 \\
\hline Johor Bahru & 957 & Muar & 7759 \\
\hline Kluang & 3311 & Pontian & 29652 \\
\hline Kota Tinggiu & 2291 & Segamat & 4746 \\
\hline Kulai Jaya & 42 & Tangkak & 12384 \\
\hline Total & & & 107731 \\
\hline
\end{tabular}

Source: Department of Agriculture (2017)

\subsection{Cost Benefit Analysis (CBA)}

According to Shively and Galopin (2013), Cost Benefit Analysis is a valuable tool for decision making for each management. Quantitative data have been used in CBA to back up qualitative arguments and CBA is most useful to evaluate the project for an early stage of project. In addition, CBA is important to make comparison between investment and project. The comparison is made easier to exclude bad project from consideration because all investment using similar method. CBA is also mainly used to assist the decision making of management, and helpful in choosing the suitable project and maximizing the profit by getting the lowest cost. Besides that, another purpose of CBA is to help the management to select among alternative projects that will get more revenue and improve service standard of management. Lastly, CBA is beneficial in order to facilitate self-evaluation and self-actualisation. The purpose is to determine whether the alternative project will generate profit or not. There are few methods to conduct CBA including Net Benefit Analysis, Present Value Analysis, Net Present Value, Internal Rate Return, and Cost Benefit Ration (Dugan et al., 2006). Misuraca (2014) explained that Cost Benefit Analysis is a process of using theory, data and model to measure the products and alternative solutions. The function of CBA is to help in making decision for choosing the best alternative that generates larger profit than cost. In addition, Makowsky and Wagner (2009) explained that CBA is a mathematical tool to examine which project will provide greater benefit or loss. Additionally, Bumbescu and Voiculesu (2014) further elucidated that Cost Benefit Analysis is a tool to estimate revenue and cost for a particular project. Management need to calculate all the cost of project and choose the project if it is profitable. In addition, CBA has been commonly used in investment project such as construction, industry, transport, tourism and agriculture. Researchers have often highlighted the main objective of CBA is to identify cost and benefit of project based on financial, economic, social, environmental and other factors that are related to the project. Benefit-cost ratio (BCR) is defined as:

$$
B C R=\sum_{i=1}^{n} \frac{R_{i}}{(1+r)^{i}} / \sum_{i=1}^{n} \frac{C_{i}}{(1+r)^{i}},
$$

where $R_{i}$ and $C_{i}$ represent the total revenue and total cost in period $i$, given the interest rate of $r$, respectively. Thus, the overall formula of BCR is by dividing the sum revenues generated during production life over the sum of cots incurred. A Simple budgetary approach was used to calculate the total cost, total revenue and net return in Eq. (1).

$$
\mathrm{TC}=\mathrm{TFC}-\mathrm{TVC},
$$

where TC, TFC and TVC denote Total Cost, Total Fixed Cost and Total Variable Cost, respectively.

\subsection{Multiple Regression}

The analysis of the data is conducted using the STATA application. A multiple regression refers to a set of technique for studying the straight-line relationship among two or more variables. Multiple regression is statistical tool to examine how much independent variable have related with coconut production. The empirical model of the effects on coconut production of a set of explanatory variables is defined using the following relation:

$$
Y=\beta_{0}+\beta_{1} X_{1}+\beta_{2} X_{2}+\beta_{3} X_{3}+\beta_{3} X_{4}+\beta_{4} X_{4}+\beta_{5} X_{5}+\beta_{6} X_{6}+\beta_{7} X_{7}+\beta_{8} X_{8}+\beta_{9} X_{9}+\beta_{10} X_{10}+\varepsilon,
$$

where $Y$ is the dependent variable (production of coconut as a proxy variable for profits); $X_{1}$ is the planting area (Acre); $X_{2}$ is the fertilizer (Kilogram); $X_{3}$ represents the fungicide (Litre); $X_{4}$ is an extension visit (frequency of visit); $X_{5}$ denotes the transportation cost (RM); $X_{6}$ represents education (years); $X_{7}$ is gender (dummy variable $1=$ male, $0=$ female); $X_{8}$ is secondary education, $(0=$ primary education $) ; X_{9}$ is tertiary education, $(0=$ primary education $) ; X_{10}$ is labor cost $(\mathrm{RM}) ; \beta_{0}$ is constant; $\beta_{1^{-}}$ $\beta_{\mathrm{n}}$ are the coefficients to be estimated and $\varepsilon$ is the error term. 
The values of each independent variables and some socio demographic features of producers such as gender of smallholders, farming size and experience of smallholders were used in this model as independent variables to regress on dependent "Y" factor, i.e. coconut production

\section{Results and Discussions}

\subsection{Socio-economic Characteristics of Respondents}

According to Table 2, all the smallholders involved in the coconut industry were majority males and only 34 respondents were female. The complex harvesting tasks, which require a lot of energy, might be the deterrent for female smallholders to be involved in the activities (El Pebrian \& Yusof, 2016). Table 2 shows that most of the smallholders in the Batu Pahat, which involved 114 respondents (75\%) had the average age of 50 years old until 69 years old. There was one (1) smallholder who was single. Even though most of them were married, their family basically comprised 4 to 6 members only. So, it can be said that the smallholders generally had small families. Most of the coconut smallholders possessed secondary education which accounted for $62.5 \%$ (95). The remaining $36.2 \%$ (55) coconut smallholders completed primary education and only $1.3 \%(2)$ of the coconut's smallholders attending tertiary education or university level. The majority of the smallholders were Malays (90.8\%) and only $9.2 \%$ were Chinese. The result also shows that most of the smallholders were in full time planting mode in the coconut industry. The percentage of full-time respondents is $94.5 \%$ while part-time smallholders is $5.5 \%$. There were 48 smallholders (31.6\%) who had 41-50 years of experience or involvement in activities related to coconut industry. This is in line with the fact that most of the smallholders in the three districts were mostly middle-aged generation. As the activities were still being carried out in the locations under study, it was learned that the older generation had passed the knowledge related to coconut production activities to the younger generation so as to continue the tradition and satisfy the demand. All the smallholders originated from Malaysia and $99.3 \%$ of smallholders had their own land holdings. Only one smallholder had a shared farm land. It showed that the majority of the smallholders had small land holdings between 1.0 acre and 2.0 acres. This is followed by 50 smallholders that owned 3.0 acres to 4.0 acres and only one person that had more than 7 acres of field size.

Table 2

Socio-economic Characteristics of Respondents (by Frequency)

\begin{tabular}{|c|c|c|c|}
\hline Variable & Categories & Number of respondents & Percentage (\%) \\
\hline \multirow{2}{*}{ Gender } & Male & 118 & 77.6 \\
\hline & Female & 34 & 22.4 \\
\hline \multirow[t]{4}{*}{ Age (years old) } & $19-29$ & 3 & 2.0 \\
\hline & $30-49$ & 27 & 17.7 \\
\hline & $50-69$ & 114 & 75.0 \\
\hline & $70-79$ & 8 & 5.3 \\
\hline \multirow[t]{3}{*}{ Marital Status } & Married & 151 & 99.3 \\
\hline & Single & 1 & 0.7 \\
\hline & Separated & 0 & 0 \\
\hline \multirow[t]{3}{*}{ Education Level } & Primary & 55 & 36.2 \\
\hline & Secondary & 95 & 62.5 \\
\hline & University & 2 & 1.3 \\
\hline \multirow[t]{4}{*}{ Race } & Malay & 138 & 90.8 \\
\hline & Chinese & 14 & 9.2 \\
\hline & Indian & 0 & 0 \\
\hline & Others & 0 & 0 \\
\hline \multirow[t]{2}{*}{ Planting Mode } & Full time & 143 & 94 \\
\hline & Part time & 9 & 6 \\
\hline \multirow[t]{6}{*}{ Experience (year) } & $0-10$ & 17 & 11.2 \\
\hline & $11-20$ & 16 & 10.5 \\
\hline & $21-30$ & 21 & 13.8 \\
\hline & $31-40$ & 45 & 29.6 \\
\hline & $41-50$ & 48 & 31.6 \\
\hline & More than 51 & 5 & 3.3 \\
\hline \multirow[t]{2}{*}{ Nationality } & Malaysian & 152 & 100 \\
\hline & Non-Malaysian & 0 & 0 \\
\hline \multirow[t]{2}{*}{ Land Type } & Own & 151 & 99.3 \\
\hline & Sharing & 1 & 0.7 \\
\hline \multirow[t]{4}{*}{ Field Size } & $1.0-2.0$ & 84 & 55.3 \\
\hline & $3.0-4.0$ & 50 & 32.9 \\
\hline & $5.0-6.0$ & 17 & 11.2 \\
\hline & More than 7 & 1 & 0.6 \\
\hline
\end{tabular}




\subsection{Analysis of Cost Benefit and Benefit Cost Ratio}

Table 3 indicated the average of inputs and production of coconut in Batu Pahat, Johor. This included labour cost, fungicide, transportation cost and fertilizer cost. The decision rule of BCR is that if the BCR is greater than 1, it shows that the coconut production is profitable.

Table 3

Input Cost and Production of Coconut Smallholders in Batu Pahat, Johor.

\begin{tabular}{lccccc}
\hline Variable & Price 1 $(\mathrm{RM})$ & Price 2 $(\mathrm{RM})$ & Price 3 $(\mathrm{RM})$ & Price 4 (RM) & Price 5 (RM) \\
\hline Price & 0.9 & 1 & 1.2 & 1.3 & 1.4 \\
Average Output & $22,192.00$ & $22,192.00$ & $22,192.00$ & $22,192.00$ & $22,192.00$ \\
Gross Margin (RM) & $19,972.80$ & $22,192.00$ & $26,630.40$ & $28,849.60$ & - \\
Fixed cost & - & - & - & $31,068.80$ \\
Variable Cost (RM) & $3,318.00$ & $3,318.00$ & $3,318.00$ & $3,318.00$ & - \\
Total Cost (RM) & $3,318.00$ & $3,318.00$ & $3,318.00$ & $3,318.00$ & $3,318.00$ \\
Net Revenue (RM) & $16,654.80$ & $18,874.00$ & $23,312.40$ & $25,531.60$ \\
\hline BCR & 5 & 5.7 & 7.0 & $27,750.00$ \\
\hline
\end{tabular}

The finding of the profitability of coconut is present in Table 3. From the table, it can be seen that there are different prices per nut. The lowest price was RM 0.90 and the highest price per nut was about RM 1.40. The result shows that, different prices lead to different gross margins, net revenues and also different benefit cost ratios. First of all, the gross margins per acre vary, which were RM 19,972.80, RM 22,192, RM 26,630.40, RM 28,849.60 and the last one was about RM 31,068.80. The outcome of the profit also depends on different prices of the coconut nut. This is because of higher productivity and price received per nut of coconut. Meanwhile, the gross margin per acre was RM 19972.80 for the price of RM 0.90, while for the price of RM 1.00, the gross margin was RM 22,192. Next, for the price per nut of the coconut of RM 1.20, the gross margin was RM26, 630.40. Lastly, for the prices of RM 1.30 and RM 1.40, the gross margins were RM 28, 849.60 and RM 31 068.80, respectively. Thus, the smallholders will get the highest net revenue if the price per nut was about RM 1.40 and directly this price has a higher benefit cost ratio which was 8.40. In addition, the benefit cost ratio varies for each price. The highest benefit cost ratio was about 8.40 from the price of RM 1.40 and the lowest benefit cost ratio was about 5 from the price of RM 0.90 . Based on the results, all the benefit cost ratios have the values of more than 1 and this directly gives more profit for the smallholders. In case for the highest cost benefit ratio, the farmers gain highest revenue of RM8.40 for an additional Ringgit spent on coconut production cost.

\subsection{Multiple regression Analysis}

\section{Table 4}

Multiple Regression Analysis

\begin{tabular}{llll}
\hline Coconut Production & Coefficient $\beta$ & t-ratio & Standard error \\
\hline Constant & $-37743.36^{* * *}$ & -4.04 & 9353.19 \\
Planting Area/acre & $3642.228^{* * *}$ & 3.27 & 1113.718 \\
Fertilizer/kilogram & -2.624425 & -0.53 & 4.981675 \\
Fungicide/litre & $1373.09^{* * *}$ & 3.53 & 389.5097 \\
Labour/man & $1539.059^{* * *}$ & 4.38 & 351.6058 \\
Transportation / RM & 10.02162 & 1.08 & 9.318578 \\
Experience / years & $237.1758^{* * *}$ & 3.03 & 78.36502 \\
Male & $4071.88^{*}$ & 1.88 & 2171.25 \\
Secondary School & $4694.415^{* *}$ & 2.15 & 2182.774 \\
Higher Education & 2356.896 & 0.29 & 8100.941 \\
Field Visit & $37.5348^{* *}$ & 2.16 & 17.38915 \\
\hline Number of Observations & 152 & & \\
R-squared & 0.5077 & & \\
Breusch-Pagan (Chi-Square) & 60.97 & & \\
F (10,141) & 14.51 & & \\
\hline ***Significant at 1\% level; **Significant at 5\% level; * Significant at 10 level\% & \\
\hline
\end{tabular}

The finding of the multiple regression is shown in Table 4, which is the most significant factor in the coconut production among the smallholders in Batu Pahat, Johor. The dependent variable for this study is the production of coconut. The independent variables are fertilizer, planting area, fungicide, labour, experience, transportation cost, gender, primary and secondary school while primary education as a base education factor. Based on the results above, it showed that the value of R-square is 0.5077 and this indicates that there are $51 \%$ of the variance in the dependent variable within the regression model are explained by all independent variables in the regression model. Meanwhile, using Breusch-Pagan test at the significance level of 1 percent $(0.01)$ 
and 5 percent (0.05), this indicates that there is no existence of autocorrelation problem with the $\chi^{2}$ value of 60.97 The outcome of the result shows that the independent variables have a significant relationship with the coconut production. The coefficient explained that the increase of $1 \%$ of the independent variable will increase or decrease the production of coconut. According to Frost (2017), a smaller R-squared value is not always a problem and a higher R-squared value is not necessarily good due the outcome variables, such as the human behaviour, which are unpredictable. In addition, a moderate value of R-squared indicates a good model and otherwise, an extremely high value of R-squared indicates a biased model. The coefficient of planting area shows that there is a positive, significant relationship with coconut production. It shows that, the increase of $1 \%$ of the planting area will increase the production to 3642 of coconut (per nut). The planting area is an important factor that will ensure that the production of coconut will be increased.

Meanwhile, field visit from extension agent has a positive, statistically significant effect on coconut production. The extension agent service in government agency is important to encourage and educate smallholders about suitable agronomical practice in their farms and thus encourage them to enhance their productivity (Adesoji, 2009). According to Sharadraj and Chandra Mohanan (2014), establishing a coconut plantation in a certain area which possess a high humidity and heavy rainfall would cause a serious problem as the bud would easily rot. This will affect the coconut's economy. For these reasons, fungicide is important to the coconut plantation as to avoid the coconut nut to be affected by diseases. Besides, the fungicide application is needed in the coconut plantation to avoid the competition of the nutrient with the weeds. Based on the Table 4 above, a 1\% increase of fertilizer and fungicide will increase the production of the coconut to 38 and 1373 (nuts) respectively, which corroborates with our prior expectation that both variables are significantly affecting the production of the coconut. In addition, labour has a positive, strong significant relationship with the production of coconut. An efficient labour will enhance the production of coconut. Labour is an important factor in the agricultural sector to ensure that the production of the agriculture will be running smoothly. In the coconut industry, most of the smallholders use labour in manuring and applying the pesticide. The workers will receive wages based on the acre and amount of pesticides that they apply. The more acres that they have to apply pesticide and fertilizer, the more wages that they will gain. By increasing $1 \%$ of the labour, this will directly increase the production of coconut to about 1539 (nuts).

The coefficient of smallholders' experience in farming has a positive coefficient and positive significant. The positive coefficient and significant in the farming experience may reflect the age of the smallholders and nature of the coconut (Adewumi and Adebayo, 2008). Majority of the smallholders are older compared to the rest of the smallholders. This shows that the older or middle-aged smallholders are knowledgeable in the coconut production. They know the right method in handling most situations in the farm. The more experience that the smallholders have, the more output that they will get and hence increase their profits.

Meanwhile, the secondary school and university level of education have positive coefficients but only the secondary level has a strong relationship with the coconut production. The smallholders that went to the secondary school rather than primary schools have better access to the agriculture information, credit and inputs. Besides, most of them know some basic accounting or at least a simple farm book record keeping to keep track with the changes in inputs and output. Based on the result, it can be concluded that the smallholders who went to the secondary schools or universities, would likely to have better profits and higher production of coconut than those who only completed primary education. Besides, the coefficient of male is positive and statistically significant in the coconut production. Based on the study, majority of the smallholders are males. Males have more strength rather than female smallholders and this directly leads to a higher production of the coconut. The complex harvesting tasks, which require a lot of energy, might be the deterrent for the female smallholders to be involved in the activities (Anwar et. al., 2015; El Pebrian \& binti Yusof, 2016). Besides, the activities require specific skills to ensure the safety of the smallholders and the smooth flow of the activities. Based on the result, it shows that the $1 \%$ increase of the male smallholders will increase about 4071 production of coconut. Other variables such as fertilizer and transportation costs, however, are found to be statistically insignificant towards the production of coconut.

\section{Conclusion}

This study has been undertaken in a consideration that coconut has been an important source of income and employment of more than 80,000 of smallholders in Malaysia. The present study has brought into focus, various issues related to socio economic status and production of coconut among smallholders. The empirical results have revealed that Benefit Cost Ratio ranging from 5.0 to 8.4, indicating that venturing into coconut production is a profitable enterprise and therefore may help smallholders to augment their income and improve livelihoods. The results from multiple regression analysis have shown that factors such as agronomic practices, government agency, knowledge of smallholders and socio economics affect the profitability of coconut production. In general, consideration such as planting area, cost of fungicide, cost of labour, experience and education level, field visit by extension services are important as they directly influence the quantity and quality of coconut production and hence the profits. The provision of good fertilizers, as well as transportation and logistics should be further enhanced to ensure higher profitability among coconut smallholder production. 
As agribusiness in general requires quick understanding, skills such as farm record keeping and accounting skills, labor and pest management and the ability to choose a profitable enterprise and adaptable to changes and risks are therefore crucial. All the complexities in the industry are achievable through better education and knowledge. Marketing information is very important to get better access to the market. The availability of market information with regard to prices may help a smallholder to choose marketing channels and make decisions of each market to ensure better profits. In addition, field visit from extension agent is important in improving dissemination of technological information among smallholders in coconut industry. Other efforts such as seminars, workshop or integrated training approaches are required so that smallholders may respond to the needs of a more modern agricultural sector and information and communication technologies to ensure effective delivery and improve their profits and capacities in a collective action.

\section{Acknowledgment}

The authors gratefully acknowledge the financial support of Lestari Grant, UiTM (Grant No: 600-IRMI/DANA 5/3/GOT $(001 / 2018)$ to carry out this study.

\section{References}

Adewumi, M. O., \& Adebayo, F. A. (2008). Profitability and technical efficiency of sweet potato production in Nigeria. Journal of Rural Development, 31(5), 105-120.

Adesoji, S.A. (2009). Assessment of agricultural extension agents' marketing-related services: Implication for policy makers in Ekiti State, Nigeria. Journal of Agricultural \& Food information, 10, 334-347.

Akinbile, L.A., \& Otitolaye, O.O. (2008). Assessment of extension agents' knowledge in the use of communication channels for agricultural information dissemination in Ogun State, Nigeria. Journal of Agricultural \& Food Information, 9, 341-353.

Anwar, R., Abdul Fatah, F., Othman, N., Nawawi, A. H., \& Tajuddin, Z. (2015). Socioeconomic Study of Arenga pinnata Smallholders in Malaysia. In Proceedings of the International Symposium on Research of Arts, Design and Humanities (ISRADH 2014) (pp. 113-125). Springer, Singapore.

Asfaw, A., \& Admassie, A. (2004) The role of education on the adoption of chemical fertilizer under different socioeconomic environments in Ethiopia. Agricultural Economics, 30, 215-228.

Bumbescu, S. S., \& Voiculesu, A. (2014). Cost benefit analysis and its role in investment projects in agriculture. Hyperion Economic Journal, 4(2), 44-53.

Christoplos, I. (2012). Climate advice and extension practice. Geografisk Tidsskrift- Danish Journal of Geography, 112, 183193.

Dugan, R. E. (2007). Measuring Your Library's Value: How to Do a Cost-Benefit Analysis for Your Public Library. By Donald S. Elliott, Glen E. Holt, Sterling W. Hayden, and Leslie E. Holt. Chicago: American Library Association, 2007. 181pp. \$55.00 (\$49.50, ALA members). ISBN 10-0-8389-0923-X. 0. Library \& Information Science Research, 29(4), 576-579.

El Pebrian, D., \& Yusof, Z. (2016). Analysis of human energy expenditure in harvesting sugar palm (Arenga Pinnata Merr) in Malaysia. Agricultural Engineering International: CIGR Journal, 18(1), 149-157.

FAOSTAT (2016). Production of Coconut in the World.

Frost, J. (2017). How to interpret R-squared in Regression Analysis. Retrieved from http://statisticsbyjim.com/regression/interpret-r-squared-regression/ Accessed on 02 June 2018.

Green, A. H. (1991). Coconut production: present status and priorities for research. World Bank Technical Paper, 136.

Herath, C. S., Chandrarathna, J. P. T. R., \& Abewickrama, S. W. R. K. (2015, December). Major problems encountered by the coconut growers who visit coconut technology park of coconut research institute of Sri Lanka. In COCOS (Vol. 20, pp. 18). Coconut Research Institute of Sri Lanka.

Malik, H. (2011). Determinants of insurance companies profitability: an analysis of insurance sector of Pakistan. Academic Research International, 1(3), 315.

Hussain, I., \& Hanjra, M. A. (2004). Irrigation and poverty alleviation: review of the empirical evidence. Irrigation and drainage, 53(1), 1-15.

Krejcie, R.V. \& Morgan, D.W. (1970). Determining sample size for research activities. Educational \& Psychological Measurement, 30, 607-610.

Laksana, Budi Setyo (2003). Karakteristik Demografi dan Sosial Ekonomi Pekerja Wanita pada Perusahaan Rokok "Alam Subur” Kraksaan Probolinggo. http:digilib.itb.ac.id (14 Januari 2017).

Makowsky, M. D., \& Wagner, R. E. (2009). From scholarly idea to budgetary institution: The emergence of cost-benefit analysis. Constitutional Political Economy, 20(1), 57-70.

Misuraca, P. (2014). The effectiveness of a costs and benefits analysis in making Federal Government decisions: A literature review. The MITRE Corporation.

Naik, A., C Madhusudhan, M., Raghavarao, K. S. M. S., \& Subba, D. (2015). Downstream Processing for Production of Value Added Products from Coconut. Current Biochemical Engineering, 2(2), 168-180. 
Pham, L.J. (2016). Coconut (Cucus nucifera), Editor (s): Thomas A. McKeon, Douglas G. Hayes, David F. Hildebrand, Randall J. Weselake. Industrial Oil Crops, AOCS Press, pp. 231-2432. ISBN 9781893997981.

Plucker, J. A. (2003). Exploratory and confirmatory factor analysis in gifted education: Examples with self-concept data. Journal for the Education of the Gifted, 27(1), 20-35.

Rivera, W.M. (2011). Public sector agricultural extension system reform and the challenges ahead. Journal of Agricultural Education and Extension, 17, 165-180.

Sivapragasam, A. (2008). Coconut in Malaysia: Current developments and potential for re-vitalization. 2nd International Plantation Industry Conference and Exhibition (IPICEX2008), (November), 1-9.

Sharadraj, K. M., \& Mohanan, R. C. (2014). A new detached coconut leaf let technique for bioassay of fungicides against Phytophthora palmivora-the incitant of coconut bud rot. International Journal of Plant Protection, 7(1), 161-165.

Shively, G., \& Galopin, M. (2013). An overview of benefit-cost analysis. Accessed online at http://www.agecon. purdue. edu/staff/shively/COURSES/AGEC406/reviews/bca. htm.

Vinodhini, C., \& Deshmukh, K. V. (2017). An Economic Analysis of Coconut Farming in Karur District of Tamil Nadu, India. International Journal of Current Microbiological Application Science, 6(12), 1566-1573.

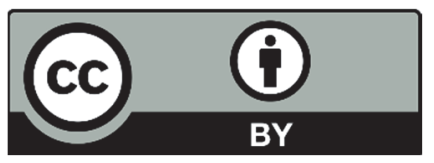

(C) 2020 by the authors; licensee Growing Science, Canada. This is an open access article distributed under the terms and conditions of the Creative Commons Attribution (CC-BY) license (http://creativecommons.org/licenses/by/4.0/). 